\title{
THE LABOR FORCE: ITS RECRUITMENT AND TRAINING
}

\author{
JOHN J. CORsON*
}

War has always drawn heavily on the combatant nations' resources in manpower. World War II is destined to tax the human resources of the United States to an even greater degree than has been the case in wars of the past. This country must, first, recruit the largest army in its history. Second, it must recruit an army of industrial workers sufficient to produce the munitions and equipment for this army while maintaining production sufficient to meet the essential needs of the civilian population for goods and services. And, third, it must allow for additional industrial and agricultural production sufficient to assure the foodstuffs, planes, guns, tanks, and ships required by our allies.

What are our human resources for the tasks upon which our future as a free people depends? In December $1940^{1}$ the labor force comprised 53.2 million persons, of whom all but 7.I million were employed. At the time of the last census, in March 1940, some 10.5 million workers were employed in manufacturing, 7.5 million in wholesale and retail trade, 2 million in construction, and 8.4 million in agriculture. ${ }^{2}$

Available figures for $194 \mathrm{I}$ and estimates for future years, ${ }^{3}$ however, demonstrate that the size and distribution of the labor force is changing materially. For instance, from December I94I to December 1942 the total labor force increased 3.3 million or about $6 \%$, while the number in war employment rose ro. 6 million or about $150 \%$. Thus it is expected that by December 1942 this nation's labor force will number 53.2 million, ${ }^{4}$ of whom all but 2.4 million will be employed. Of the 50.8 million employed, some 17.5 million or about $34 \%$ will be employed in war in-

- B.S., 1926, M.S., 1929, Ph.D., 1932, University of Virginia. Director of the Bureau of Employment Security and Director of the United States Employment Service, Social Security Board, since December, 1941; also Chief of the Industrial and Agricultural Employment Division, War Manpower Commission, since June, 1942. Formerly Professor of Economics, University of Richmond, r933; Acting State Director, National Recovery Administration, for Virginia, I934-1935; Assistant Director, National Youth Administration, 1935; Assistant Executive Director, Social Security Board, 1936-1938; Director, Burcau of Old-Age and Survivors Insurance, Social Security Board, 1938-194r. Author of OuR GovenNMENT (with others) (1939); Employer-Employee Relations in Public Service (I940); various studics of social and economic problems in Virginia (with W. P. Gee). Contributor to periodicals.

${ }^{I}$ These figures represent the joint estimates of the Bureau of Labor Statistics of the U. S. Department of Labor and the Bureau of Employment Security of the Social Security Board.

${ }^{2}$ U. S. Dep't of Commerce, Bureau of the Census, Sixteenth Census of the Unitrd States: 1940, Series P-I0, No. II (April 29, 1942).

${ }^{8}$ Labor force estimates for 1942 and 1943 exclude the number or men and women in our armed forces.

See note 1, supro. 
dustries. By December I943, it is estimated, our labor force will have increased to about 53.3 million persons and the number in war industries to 20 million, an increase of about $15 \%$ over 1942 and of about $190 \%$ over $194 \mathrm{I}$.

Mere attainment of this volume of labor is, of course, not enough. It is necessary also that the labor force be efficiently allocated among war industries and essential civilian industries, according to their requirements and their relative importance in the war program. To meet the President's war production schedules, which call for 8 million tons of shipping, 60,000 planes, and 45,000 tanks in 1942 , and Io million tons of shipping, 125,000 planes, and 75,000 tanks in 1943, and to attain the equally staggering farm production goals, ${ }^{5}$ workers will have to be recruited from nonessential industries and from hitherto untapped sources of labor supply. Manufacturing, for instance, will probably be using 16.5 million workers by December I942-more than double the number at the time of the r940 censusand 18.8 million by December r943. Between December I942 and December I943, employment in construction is expected to decrease from 1.7 millicn to $\mathrm{I}$ million, and in wholesale and retail trade from 6 million to 5 million. In the same period, agricultural employment is expected to decrease from 7.8 million to 7.5 million because of shortage of workers.

The Chairman of the War Manpower Commission, Paul V. McNutt, recently pointed out that although only 6.9 million workers were engaged in war work on January $\mathrm{I}$, I942, the number had increased to 12.5 million by July $\mathrm{x}, \mathrm{r} 942$, and that 5 million more workers will be needed before the end of this year. This gain in war employment, he declared, "shows that industry and Government have struck their stride in producing for war. It also shows that a very large percentage of the industrial workers in peacetime production are shifting over to war production." ${ }^{\text {" }}$

As the labor force swells, increased attention must be paid, moreover, to the incessant demand for skilled workers. The Bureau of Labor Statistics estimates that by the fourth quarter of 1942 no fewer than $32 \%$ of the total number of workers engaged in war-goods manufacturing will be skilled workers, $44 \%$ will be semiskilled, and the remaining $24 \%$, unskilled. Already shortages of skilled workers in critical lines such as metal trades, aircraft, shipbuilding, and ordnance are affecting production schedules. One of the most effective methods for combatting these shortages is training.

The three big problems ahead of us, then, are the development of an adequate total labor supply, the most effective allocation of labor among industries, and the training of a sufficient proportion of skilled workers. Since the problem of allocation is considered elsewhere in this publication, ${ }^{7}$ I shall discuss two of these problems-recruitment and training. Energetic recruitment and comprehensive train-

\footnotetext{
The goal of our "Food-for-Victory" program for I942 includes: I25 trillion pounds of milk, 3.8 billion dozen eggs, 83 million hogs, 95 million acres of corn, and 40 million acres of tomatoes.

- War Manpower Comm'n Release PM-3760, July 13, 1942.

${ }^{7}$ See Stocking, Allocation of Manpower, infra at p. 430 .
} 
ing can ensure our ability to meet the needs of our industries both as regards quantity-the labor supply-and quality-the required skills.

\section{SOURCES OF LABOR Force}

Workers in the labor market. To expand our labor force sufficiently, workers must be recruited from sources which hitherto have been untapped and present labor must be more effectively utilized. We now have several million partially employed workers, part-time workers, and casual workers. ${ }^{8}$ Full-time employment for every man and woman now employed means a greater total volume of labor. In other words, the goal is not only a greater total labor force but also a full-time labor force.

Many additional workers will be recruited from among persons now employed in nonessential industries. In December 194I, 29.x million persons were engaged in non-war production. For December 1942, the number so employed is estimated at 20.5 million and for December 1943, at 19.1 million-a decrease of $34 \%$ in 2 years. This transfer of labor will be accomplished by curtailing all but essential civilian production, by converting nonessential plants to war work, by conserving machinery, and by concentrating production so that men and plants are working at full capacity.

As of May 1942, it is estimated, the labor force included some 2.6 million unemployed persons, including employable and so-called "unemployable" individuals. No hard-and-fast line can be drawn between these two categories. When the demand for workers is great, employers are willing to give the hitherto unemployable a chance to fit in. "Employability," therefore, depends in part on the times. In Great Britain, studies of experience with so-called unemployable persons revealed that a large proportion could be used in the war effort after a period of readjustment and training. To accomplish this result, special effort is undoubtedly necessary, but it is effort well expended. A significant proportion of the unemployed is made up of Negroes and members of other minority groups who because of race, color, or creed, find it difficult or impossible to get jobs. As the demand for labor bears more and more heavily on the available supply, these workers will also be called to employment.

According to the National Industrial Conference Board, unemployment in April I940 totalled 9 million. For the same month in 1942, the figure was about $x .7$ million. The Work Projects Administration estimated the number of unemployed workers at 8.8 million in April r940 and 3 million in April 1942. Thus, on the basis of two different types of unemployment estimates, the ranks of the unemployed had shrunk by from 7.3 million to 5.8 million. The so-called "hard core" of unemployment-the groups of workers who have been without jobs for many years-is rapidly dissolving.

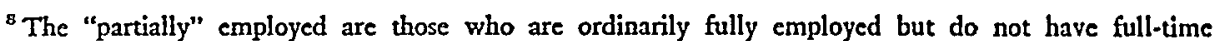
weekly employment. "Part-time" workers are those who, generally through choice, work only a part of the time each week. "Casual" workers are persons engaged in lines of work which do not occupy them regularly and which are generally outside their usual occupations.
} 
"Additional" workers" not ordinarily in the labor market. A main source of additional workers is to be found among younger married women who live in industrial centers. Only a relatively minor portion of the additional female workers can be drawn from the ranks of unmarried women, since a large proportion are already gainfully employed or are responsible for the care of families. ${ }^{10}$ Because most of the increase in labor supply will be needed in the centers of war production, comparatively few women can be taken from the rural areas and small towns. However, housewives with young children, whether they live in rural or industrial areas, will be unable to accept employment unless adequate arrangements are made to care for the children. The Bureau of Labor Statistics has estimated that there are 4.9 million non-farm housewives who are aged less than 45 and have no children under age ro. These women are generally considered the most likely to be employable. The number of non-farm housewives aged 45 and over has been estimated at 9.3 million. Unless we recruit nearly every woman under 45 who has no young children, it will be necessary to draw heavily on non-farm housewives over age 45 . The younger group will be employed in full-time essential jobs; the older group, in whatever full-time work is suitable, in part-time work, and in volunteer activities.

It will be necessary to overcome existing prejudice against the training and hiring of older women. Prejudice against women workers in general, like that against various minority groups, has far from disappeared. Recent surveys of the Bureau of Employment Security indicate that, although women are capable of working in four fifths of the occupations in war industries, they are found in only a tenth. In January I942 the Bureau made a special study of the employment of women in more than 12,000 war-industry establishments which expected to hire about 676,000 additional workers by June I942. The study revealed that employers did not plan to employ women in over two thirds of the anticipated skilled jobs and $82 \%$ of the professional and managerial jobs. It is most significant that experience with women workers has been favorable in plants concerned with ammunition, electrical machinery, rubber products, nonferrous metal, and aircraft. Such experience, together with the continued transfer of male workers to the armed forces, will eventually dissipate these prejudices.

Another source of additional workers lies in our youth, including those attending school, high-school graduates, and young people leaving school in order to enter employment. It is relatively easy to recruit workers from among the approximately 2 million students aged 18 years and over. They are usually eager to get jobs, and the problem here is not recruiting, but appropriate training. Of greater

- This interesting subject has evoked much comment from economists. See Woofter, Will Defense End Unemployment? (May, I94I) HARPERs, 625-630; Woytinsky, Additional Workers and the Volume of Unemployment, Social Science Research Councti, Paxpp. Series No. I (Jan. I940); and Humphrey, Alleged "Additional Workers" in the Measurement of Unemployment (June 1940) $48 \mathrm{~J}$. OF PoL. Econ. 412-419.

10 "Only about 6 percent of the homemakers are single, in contrast to the more than 53 percent found among women in the labor force." (July 1942) 5 Soctar. Security Bulk. No. 7 . 
concern is the large number of young boys and girls, who in large numbers are leaving school and entering the labor market. ${ }^{11}$ Because of their youth and inexperience, these workers require careful supervision and protection from hazards. The age group I4-18 years contains nearly to million boys and girls of whom 4.8 million are $I_{4}$ and $I_{5}$ years of age and 4.9 million are 16 and $I 7$ years. These youngsters are taking many kinds of jobs such as those of messenger boys, helpers in stores, machinists' helpers, machine operators, and attendants at amusement places. From $194^{\circ}$ to I94I, placements by the United States Employment Service (USES) of youngsters aged $16-17$ years increased $85 \%$ and of those in the lower age group, $79 \%$. These figures fail to tell the whole story since they do not include large numbers of children who work on farms.

The labor force is being expanded by the increasing numbers of retired workers, who are voluntarily returning to industry, at least for the duration, as well as those who are staying at work at ages when they expected to retire. Some of these older men are taking the place of employed younger men who are drafted or transfer to war production. Others are, themselves, working in essential war production jobs in lines in which they had previously worked. An increasing number of persons age 65 and over are not applying for old-age and survivors insurance benefits, though eligible, or are actually giving up their monthly benefit for jobs. It is estimated that about half a million workers, qualified for retirement benefits under the Social Security Act, are continuing to work. From 1940 to 1941 the number of workers awarded monthly retirement benefits under the federal old-age and survivors insurance system decreased $13 \%$.

Still another source of additional labor is found among the physically handicapped. It is estimated that there are approximately 2.2 million physically handicapped persons between the ages of $x 7$ and 64 in the United States. A survey of 68 of the country's largest industrial corporations, conducted by the National Industrial Conference Board, ${ }^{12}$ revealed uniformly favorable experience among companies which employed physically handicapped persons. Blind workers performed satisfactorily on assembly lines, in tasks requiring manual dexterity, and as typists. Persons with defective hearing were found particularly adept at inspection work. The problem in the recruitment and training of physically handicapped persons is essentially that of adapting the job to the worker rather than the worker to the job. The possibility of salvaging human assets and freeing this group from economic dependency will compensate for the extra effort needed to recruit and train the physically handicapped.

Miscellaneous sources of labor supply. Workers engaged in multiple jobs and vacation work do not properly belong in the economic concept of "additional"

\footnotetext{
21 This group does not include an estimated number of 700,000 who have regularly been leaving school each year.

${ }^{12}$ Knox, Employment of Handicapped Persons (Dec. 194t) 3 Conf. Bd. Mannaement Recond I51154.
} 
workers. However, since they do "add" to the labor force, their labor potentialities must also be considered. In some states, teachers may hold two jobs, one in a day school and one in a night school. This principle can be extended among persons engaged in seasonal work. For example, there can be increased employment of farmers and other seasonal workers in local essential industries during off-seasons. By allowing school credit for certain types of work, schools can stimulate vacation employment of teachers and students. Many of the self-employed, who number about 6 million, are in businesses which are suffering because of priorities, curtailment, and material shortages; such persons can supplement their earnings by taking essential jobs.

Inmates of prisons, interned aliens, and prisoners of war constitute other sources of labor. Among the 160,000 inmates of state prisons, about 40,000 are trained industrial workérs, 40,000 to 50,000 are unskilled and semiskilled, and from 15,000 to 20,000 are farm workers. It is estimated that they can produce about $\$$ roo million of war materials annually. We can recruit workers also from among the approximately 100,000 Japanese who have been evacuated from the West Coast for the duration of the war. If we are called upon to feed, house, and clothe prisoners of war, we should be prepared to utilize them in essential war work wherever possible.

Measures to increase productivity. To complete our inventory of sources of labor, certain factors which lead to increased production must be considered. One such measure is increasing the hours of work of the individual workers, or overtime. There has been considerable controversy as to the merits and demerits of overtime, and critics and proponents alternately point to British and German experience as proof of either position. In view of the difference in production methods, however, it is not certain to what extent we can safely draw comparisons based on the industrial experience of other countries. Undoubtedly, excessive overtime work here, as elsewhere, will increase fatigue, which in turn will increase the accident, sickness, and general absenteeism rates. The hazards are further aggravated by the increased tempo of war production, the introduction of new machinery, and the use of new workers. ${ }^{13}$

In the interest of increased "worker efficiency and production," eight United States Government agencies have jointly subscribed to a statement urging employers in war production to limit working hours in their plants to 48 hours a week and 8 hours a day. The interdepartmental statement pointed out that irregular and excessive hours of work on private and public war projects have resulted in "labor piracy," increased accidents, absence from jobs, illness, and a deterioration in quality of work. ${ }^{14}$ Under these circumstances, reliance on hours of work alone to increase

${ }^{13}$ According to the Bureau of Labor Statistics, accidental deaths and permanent total disabilities in industry increased from $I 6,400$ in 1939 to $I 8,000$ in 1940 and disabling injuries from 1.4 million in 1939 to 1.9 million in 1940 .

14 Statement issued on July 28, r942, by a committee representing the War, Navy, Commerce, and Labor Departments, Maritime Commission, War Manpower Commission, War Production Board, and U. S. Public Health Service. 
output can only be regarded as foolhardy. However, hours of work can be increased judiciously if at the same time every care is taken to guard against fatigue and to preserve the workers' health by installing proper safety devices and adequate first aid and medical facilities, and by maintaining satisfactory working conditions. ${ }^{10}$

Other measures whereby production can be increased include upgrading and job simplification. Workers in a plant can be upgraded successively to the jobs next higher in line as openings occur. Such workers require shorter periods of training and adjustment than do new workers. Jobs requiring highly skilled workers can be broken down into component parts and filled by semi-skilled and unskilled workers who may require little or no training to perform the simplified tasks. In other words, we can apply the principle of the division of labor to individual jobs.

\section{RECRUItING ActivitiEs of USES}

This inventory of our labor resources, summarized in the preceding pages, has touched on "employed" workers, "additional" workers, miscellaneous groups, and measures to increase productivity. My purpose in giving this summary has been twofold-to call attention to the many untapped sources of labor supply and to indicate the magnitude of the task which confronts the United States Employment Service in fulfilling its responsibilities for labor recruitment. In the words of President Roosevelt, "Now that this country is actually at war it is more than ever necessary that we utilize to the fullest possible extent all of the manpower and womanpower of this country to increase our production of war materials. This can only be accomplished by centralizing work recruiting into one agency."10 This agency-the USES-has thus been charged with the responsibility for rationalizing the labor market and eliminating waste in the use of the labor force.

Since January I, 1942, when the USES became a nationally operated organization, it has comprised some 1,500 full-time offices located in the business and industrial centers of the nation and about 3,000 part-time and itinerant offices operating in less populous and outlying communities. During this period, the USES has curtailed or eliminated a number of its functions which, though appropriate and useful in peacetime, were not contributing directly to the war effort. Its present functions are designed primarily to serve establishments engaged in essential activities. By directing workers to jobs in essential production with a minimum loss of time between jobs, the USES is contributing to the expansion of the labor force.

${ }^{15}$ On the basis of a survey of 140 companies employing 2 million workers, J. Douglas Brown came to the following conclusions: ( 1 ) optimum of hours of work are approximately 8 per day and $4^{8}$ per week, (2) opinion and experience both indicate a lower optimum for women than for men, (3) workers need one day of rest in seven, (4) in any upward change in hours, special attention should be given to attendance and safety, (5) the need for longer hours should be made clear to the employees and the results in terms of productivity given to them regularly, and (6) in determining optimum hours for maximum productivity, the length of the emergency period must be considered. Brown, Optimus Hours of WORk IN WAR Production (Industrial Relations Section, Dept. of Economics and Social Institutions, Princeton Univ., I942).

${ }^{10}$ Quoted from the telegram sent to all Governors on December 19, 1941, concerning the establishment of a nationally operated United States Employment Service. 
Fortunately, even before the declaration of war, steps had been taken which prepared the USES for its emergency duties. A registration system, which has been in use since 1933, provided a record of the skills, training, experience, and work preferences of large numbers of applicants at the employment offices. Aptitude and vocational tests designed to measure an individual's fitness and capacity for many types of employment and occupations had been developed. In a project that has attracted nation-wide attention the USES compiled the Dictionary of Occupational Titles, $^{17}$ a work that defines and classifies more than 17,000 specific jobs in over 130 industries. This vast sum of organized information has enabled the local offices to determine readily the niche which the individual worker can best fill in our war and essential civilian industries and has helped to determine the type of war production to which a plant can be converted most readily.

Moreover, in the Farm Placement Service, a means was provided to facilitate the placement of agricultural workers in their customary work. The Farm Placement Service collects and makes available important information on the seasonal demand for labor in various areas, the extent of the demand, the nature of the work, its anticipated duration, and wages offered. In a radio address to the Nation on March 9, 1942, President Roosevelt declared that "food, like the tanks and planes, is absolutely indispensable to victory." The agricultural program has thus been officially recognized as an essential part of our direct war effort as well as an essential civilian activity.

The USES was not confronted, like many other war agencies, with the necessity of starting from scratch in tackling recruitment and training problems. In addition to the activities already established, however, new methods had to be applied and old methods expanded.

Among the steps the USES has taken in recent war months to facilitate recruitment and training is a basic occupational inventory of all men between the ages of I8 and 65. This National Occupational Inventory, which has been conducted in cooperation with the Selective Service System, is a primary step in organizing an orderly recruiting program. It provides information as to male workers and their skills which was not available under the former registration system of the USES. It includes professional and managerial workers, who seldom register with the employment service, as well as workers with skills in critical occupations who might never have registered. On the basis of these questionnaires, the USES will classify all employed and unemployed men into (I) critical occupations, (2) essential occupations, and (3) neither critical nor essential occupations. ${ }^{18}$ The first group will be further classified to indicate men working at a critical occupation on an essential product and men not so employed. The immediate objective of this sorting pro-

\footnotetext{
${ }^{17}$ In 4 parts, prepared by the Occupational Analysis Section, U. S. Employment Service Division, Bureau of Employment Security, Social Security Board, Federal Security Agency (I939, I94I).

1s A "critical" occupation is one in which the reported national demand is greater than the available supply. An "essential" occupation is one in which a shortage does not now exist but is anticipated and for which training cannot be completed within approximately 6 months.
} 
gram is to provide a basis for orderly recruiting of the labor force for those occupations in which critical and essential shortages exist.

Clearance ${ }^{10}$ is another device utilized by the USES to facilitate the recruitment of workers for essential war industries. To put the clearance procedure on a war footing, the USES has urged employers to use their employment representatives as authorized hiring agents. Thus, if the local employment office is unable to fill the employer's order, the employment office locates properly qualified workers and arranges a time and place for bringing them and the employer's agent together. The agent interviews the workers and can hire them on the spot and also make transportation arrangements.

Because of the war program, the demand for farm labor now exceeds the availably supply, especially in Texas and the Far West. Since the migratory labor on which many farmers ordinarily rely is not appearing, perishable fruit and vegetable crops are endangered. As a result, demand has arisen for importing Chinese and Mexican labor from Mexico and Cuba. ${ }^{20}$ To recruit farm labor, the USES, when the situation in a farm area becomes crucial, appeals to the community in a truly democratic fashion. Many communities have cooperated inspiringly. Housewives, businessmen, elderly persons, and school children have volunteered to harvest the local crops, while their communities have provided bus service and picnic lunches. Valuable crops which would otherwise have gone to waste have thus been saved.

Increasingly, the USES is endeavoring to recruit workers to meet the specific needs of essential employers for immediate hiring as well as definite commitments concerning the specific numbers and types of workers to be requested through the employment service in the future. For instance, where the USES used to take requests from an employer for a machinist, it now requires the employer to stipulate the kind of machinist he wants. American industry, which has been famous for its precision work, may thus gain further impetus by precision recruiting.

\section{Training of Labor Force to Meet War-Production Needs}

The expansion of the labor force and its adaptation to war needs are placing increasing emphasis on the training activities of the USES and other agencies charged with responsibility for training the requisite number and kinds of workers. As the demand for labor increases, the war training program will have to lay even greater stress on increasing the labor force by training workers in the areas where they are needed and in the skills for which a demand exists. For instance, in areas

${ }^{10}$ Clearance is a procedure for the interchange between employment offices of information about unfilled jobs and/or available applicants with the object of facilitating the referral of applicants in one employment office to job openings available through another office.

${ }^{20}$ Lawrence E. Davies in N. Y. Times, July 9, 1942, p. II: "Governor Olson [California] declared that efforts still were being made to have thousands of Mexican farm laborers brought in for the heavy harvest work in the late Summer and Fall, but he, as well as other officials, were not much encouraged over the prospect. He said he would take up with C. T. Feng, the Chinese Consul Gencral here, the proposal, advanced two days ago, for the importing of 5,000 alien Chinese from Cuba and possibly 3,000 others from Mexico." 
where the available supply of experienced labor has been exhausted, increasing numbers of women and other previously nonemployed groups must be trained. The skills needed for critical and essential occupations, such as arc welder, engine-lathe operator, ships carpenter, and loftsman, must be developed by training unskilled and semiskilled workers, workers engaged in nonessential occupations, or those with related skills. In general, the USES attempts to eliminate training which will not be utilized immediately by the trainee and for which no demand exists in the area in which the worker is trained. In certain critical occupations, however, training is recommended whether there is a demand for such workers in the local area. Training in arc welding, for example, is given wherever training facilities are available, because the demand for workers with this skill exceeds the supply and is expected to increase.

To facilitate the employment of persons without previous work experience, preemployment training is provided by the United States Office of Education in cooperation with state vocational training schools. The responsibility of the USES in connection with the preemployment training courses includes: determining employer needs and specifications, recommending suitable training and number of persons who should be trained, recruiting trainees, and placing trainees in jobs utilizing training as soon as they are ready for employment.

The training program of the National Youth Administration includes work projects designed to give inexperienced young persons basic experience in industrial types of work vital to war needs. Trainees have approximately 3 months of practical on-the-job training in NYA shops, where they learn the principal operations and use of machines and tools used in machine shops, sheet metal shops, in welding, forge and foundry work, aircraft mechanics, electrical equipment and radio manufacture, and pattern making and joinery. Other projects train young people in industrial sewing and as hospital attendants. In cooperation with the USES, the NYA is using resident centers to facilitate the transfer of workers from areas of labor surplus to localities where their services are in demand. At the Nepaug Center in Unionville, Connecticut, for example, young persons who have completed training elsewhere receive-additional training for specific work and also their subsistence while they are interviewed by the USES and referred to employers who need workers. During I941, the NYA program supplied more than 421,000 trainees for private industry, of whom 210,000 went to war industries.

Another training program for youth is conducted under the auspices of the Apprenticeship Section. ${ }^{21}$ Under this program, young persons learn a trade and become skilled craftsmen in accordance with standards approved by organized labor and employers. The Apprenticeship Section brings employers and labor together on the question of training and places at their disposal any techniques that may have been acquired through similar programs, through practical experience with

\footnotetext{
21 Transferred from the Department of Labor to the Federal Security Agency by Executive Order No. 9139, April 18, 1942, 7 FEd. REg. 2919.
} 
the training problems in a given trade, or through the dissemination of practices and procedures which it has gathered from many trades and industries.

The conversion and placement of unemployed workers has been the primary objective of the Training and Reemployment Program of the Works Project Administration. The WPA Vocational Training, Program has provided courses for needy workers who receive subsistence wages while in training. Approximately $70 \%$ of those who have completed training under this program have transferred from WPA rolls to jobs, and the balance has been absorbed rapidly. In addition, the WPA conducts an Auxiliary Shop Training Program which involves use of machine, welding, and sheet metal shops where equipment may be idle because of lack of orders or priorities. The In-Plant Pre-employment Training Program of the WPA utilizes facilities in privately or publicly operated plants. Under this program, workers have a short training period, usually about 4 weeks, while on the job. About 1,650 plants are cooperating in this program which has a record of better than $90 \%$ placement of its trainees.

The Training-Within-Industry Branch of the Federal Security Agency is concerned with training on the job. It provides a practical advisory service to employers on in-plant training, furnished under the supervision of training experts most of whom have been loaned by industry. Representatives of the Branch diagnose the training needs of individual plants, help to set up in-plant training programs adapted to these needs, and bring manufacturers in touch with training services available in the area. From September I94I through March r942, this program had served some 1,520 plants employing some r.2 million workers. TWI also runs a training program to instruct key employees-foremen, supervisors, and experienced craftsmen-in ways of passing their knowledge along effectively and quickly to less experienced workers. By March 1942, 74 individuals had received job-instructor training and had, in turn, trained and certified approximately 2,000 war-production trainers, who, in their turn, had trained about $4 \mathrm{x}, 000$ other men and women throughout the country as job instructors. Although there is no way of knowing the number of workers who have learned from these instructors, an estimate of from 300,000 to 400,000 is reasonable.

For workers who have not utilized their skills for a long time, refresher courses are available to enable them to "brush up" on their skills. For workers who wish to improve or expand their skills, there are supplementary courses which help them to qualify for more specialized or more complicated tasks. Such courses are provided under a program of Vocational Education for National Defense maintained by the United States Office of Education in cooperation with state vocational training schools. Training is provided in such occupations as aviation services, construction, drafting and blueprint reading, electrical services, machine-shop practices, radio maintenance and repair, ship and boat building occupations, and such other occupations as may be approved from time to time as essential to the operation of 
war industry. Participating in this program are more than 2,400 trade and industrial schools, representing an investment of over a billion dollars, and some 3,400 centers for out-of-school youth courses. From July I940 through January I942, more than $2 \frac{1}{4}$ million persons had received training under this program. Of the $21 / 4$ million total trainees, nearly I million who are employed in war industry have taken supplementary courses in order to upgrade them for more responsible work.

This is by no means an exhaustive résumé of the training facilities now operating to speed our war effort. It fails to take into account private commercial schools, which annually turn out thousands of secretaries, typists, bookkeepers, calculating machine operators, and other types of office workers, and also the technical schools of our colleges and universities, which provide chemists, physicists, engineers, metallurgists, radio technicians, physicians, and other workers essential to the war program.

The ultimate limits of the labor force, and the techniques used for its recuitment and training, will be determined by the course of the war. If the war is long and production goals increase, it will be necessary to rely more and more on hitherto untapped and untrained sources of labor. As women, youth, older persons, and physically handicapped individuals are drawn into our army of production, facilities to ensure their orderly entrance into the labor market become increasingly important. At the same time, every effort must be made to provide full-time jobs for the unemployed and for those not fully employed, and to use fully, in essential activities, all our resources in plants and equipment. If all these methods prove inadequate, it may be necessary to rely on compulsory measures to recruit and train the necessary workers.

The time may never come when this country will be obliged to order its men and women to work in certain industries and occupations in those areas where they are needed, or to limit the employer's right to hire and fire. We shall rely on voluntary methods and procedures unless they prove inadequate to assure our maximum war effort. If the war necessitates the use of some measure of compulsion, it is to be confidently expected that here, as under our present voluntary measures, the most effective course of action will be that mapped out on a cooperative basis, by and with the advice and consent of management and labor. 